\title{
Learning by Doing through Project Based Active Learning Technique
}

\author{
Mahadev S. Patil ${ }^{1}$, Umesh A. Kamerikar ${ }^{2}$ \\ ${ }^{1,2}$ Rajarambapu Institute of Technology, Islampur, Maharashtra, India \\ 1'mahadev.pati@ @itindia.edu \\ 2umesh.kamerikar@ritindia.edu
}

\begin{abstract}
NASSCOM report has suggested that the Indian higher education system must give skill building and practical training along with academics to give them an edge. Cooperative learning, creativity, communication, team work, self-learning, decision making and use of modern tools are the skills of $21^{\text {st }}$ century. These soft skill requirements expected from engineering students is accomplished by using active learning techniques. Teaching with active learning strategies improves students' learning level. Project Based Learning (PBL) is an active learning that offers opportunities for students to make interdisciplinary connections, address academic criteria, discover personal talents and interests develop social skills, and use current technology. Projects help learners to connect personal interests with course content as they explore it in greater depth. PBL has been implemented in Electronics Measurement and Instrumentation course at second year B Tech and learning analysis was carried out to find its impact on learning outcomes. It is observed that soft skills have been developed in learners' along with academics.
\end{abstract}

Keywords: Project based learning, Learning pyramid, Life-long learning, Co-operative learning

\section{Introduction}

Student attention, involvement and learning are achieved by adapting active learning methods. The overall development of student includes the development of personal capabilities and effective thinking skills. The active learning methods are student centric. The teacher acts as facilitator to help learners to gain knowledge and skills for presenting, applying and rediscovering the knowledge. From figure 1 of learning pyramid, it is evident that student can retain $75 \%$ when they use the learning or practice it by implementing [1-6].

\author{
Mahadev S. Patil \\ Department of E and Tc Engineering, \\ Rajarambapu Institute of Technology, Islampur, Sangli, \\ Maharashtra, India \\ mahadev.patil@ritindia.edu
}

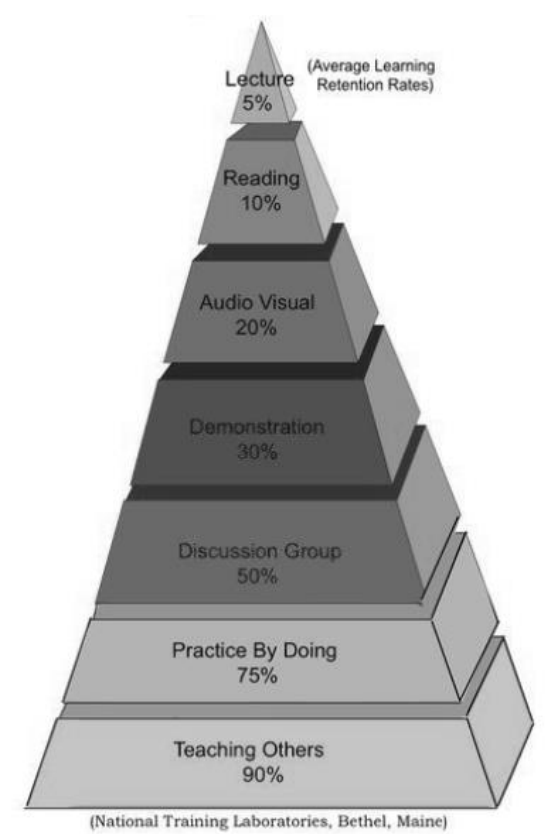

Fig 1: Learning Pyramid on basis of average retention rating in percentage of students

Project activities serve students of every academic status by accommodating different intelligences, learning styles. Also, providing more variety, choices, and options can increase student motivation. Cognitive psychological researchers indicate that these factors increase learning. The successful use of projects is facilitated by a learnercentered approach in which teachers serve as guides and facilitators. This approach encourages students to develop habits of mind that can help them become life-long learners in which learners build on their prior knowledge, experiences, and interests. Learners use primary sources of data whenever possible. Problem solving, higher order thinking and deep understanding of concepts and principles are emphasized. Learners think about their own 
thinking, assess their own work, reflect on what they are learning, and set their own goals and objectives. The role of the teacher shifts from "content expert" to "supportive coach" while learners do project work [7-11]. There is less emphasis on teacher presentation and more on providing support and structure. Generally, teacher-coaches invite and use open-ended questions; foster reflective discussion; respect and value diversity in learners and their questions; enable multiple representations of ideas, questions, and conclusions; model the tools of inquiry and investigation; and build assessment into the learning process [12-16].

There are other compelling reasons for using project-based approaches. They challenge learners to use their minds creatively, independently, and responsibly, which can give them a sense of satisfaction and accomplishment. Projects encourage students to practice working cooperatively and productively with other students, teachers, and community members. They learn to listen, speak, and reach decisions within a team. Learners also develop other skills that are vital to future academic or workforce pursuits planning, organization, research, and time management. As learners reflect on what worked well, what didn't, and how they can learn from their experiences, they be-come better monitors of their own work. Learners develop confidence and selfawareness as they use their own strengths to demonstrate learning. Products or performances that result from a project allow teachers to make a more authentic assessment of the learning that has occurred. Learners who demonstrate their mastery of content in this way reveal the depth of their understanding rather than simply their ability to recall memorized information [17-18]. The PBL activity discussed in this paper facilitates students to develop critical thinking \& problem solving skills, to improve interpersonal skills, to enhance self-directed learning, to emphasize on application of theoretical exercises to real-life problems and to work in a team.

\section{Methodology}

The purpose of PBL to strengthen the theoretical concepts by providing the platform for the learners to model, analyse, design \& test various applications thereby attaining cognitive level [8]. The PBL active learning technique was adopted to deliver sensors and transducer unit of Electronics Measurement and Instrumentation course in second year B Tech class of Electronics and Telecommunication engineering with strength of 72 students. 18 heterogeneous groups were formed with 4 students in each group. Groups are formed based on CPI of previous semester. Two students having CPI less than 7 and two students having CPI more than 7 are grouped together in one group. This is done so as to improve the abilities of less skilled learners through peer interaction in the context of a common goal. The one who are more skilled are benefitted through better clarity and feel a sense of satisfaction when they help their group mates. The PBL was planned for two months and executed from first week of August to last week of September. The sensor applications were identified and a written brief was prepared by each group followed by sensor data sheet study and circuit design. Specifications and limitations were identified. Circuit for each project was rigged up and simulated. These projects were implemented using hardware and tested. Each project was demonstrated and presented. The analysis of learning has been carried out by floating questionnaire as mentioned in table 1 .

\section{Result and Discussion}

The analysis has been carried out using rubrics to find degree of learnability after implementing project based learning. Following parameters have been included in feedback questionnaire: selection of project area and application, selection of sensor based on data sheet study, emphasis on using current tools and technologies, involvement of students in activities outside classroom, involvement of students in raising doubts, opportunities in making individual and group decisions, improvement in verbal and written skills through demonstration of project and project report. Figure 2 shows the skills achievements by learners through PBL.

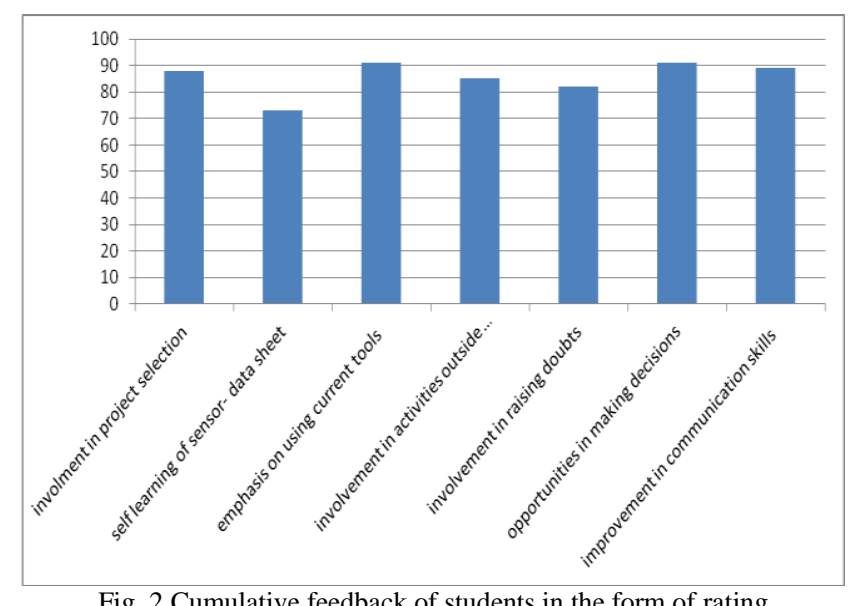

Fig. 2 Cumulative feedback of students in the form of rating

The sensors and transducer unit was taught in the previous academic year with conventional method of teaching practice and was evaluated. In the current academic year, the same topic was taught using PBL and is evaluated as In Semester Evaluation using rubrics shown in table 2 for individual evaluation. Table 3 shows the group and individual assessment sheet. The course outcome attainment has been plotted for both academic years and is shown in figure 3. From this figure, it is evident that there is improvement in course attainment of $\mathrm{CO} 3(83 \%)$ when PBL is adapted in academic year 2018-19 as compared to the attainment of $\mathrm{CO} 3(60 \%)$ when conventional delivery is used in academic year 2017-18. The CO for the unit sensor and measurement is: Apply the knowledge of sensor and transducer for various applications. The threshold based attainment calculation was carried out. 
Journal of Engineering Education Transformations, Volume 33, January 2020, Special issue, eISSN 2394-1707

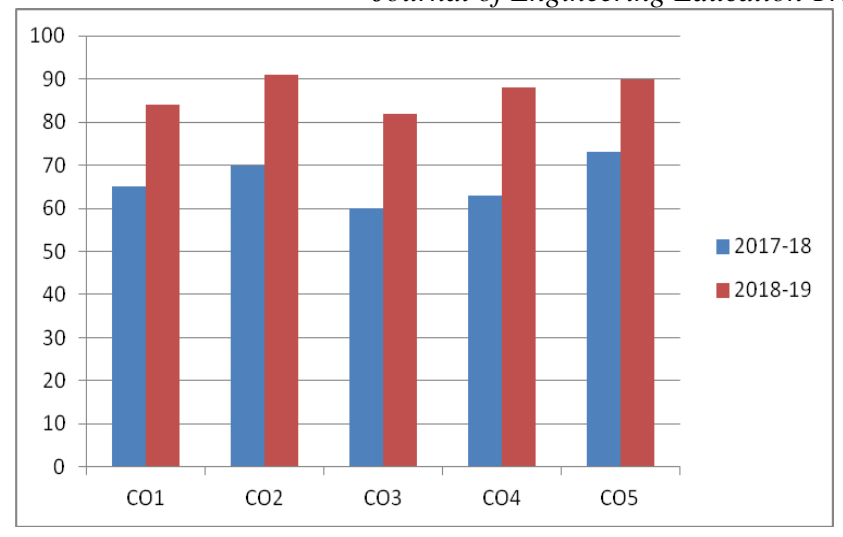

Fig. 3 Course Outcome attainment

\section{Six A's of project based learning}

Design and technology experiences challenged learners to apply their learning to a situation or problem by developing a working model. Students have used critical thinking, analysis, group decision making, and evaluation skills. Learners have used simulation tools, PCB fabrication tool. Learners having no or less experience of team work have developed team work skill and cooperative learning habit.

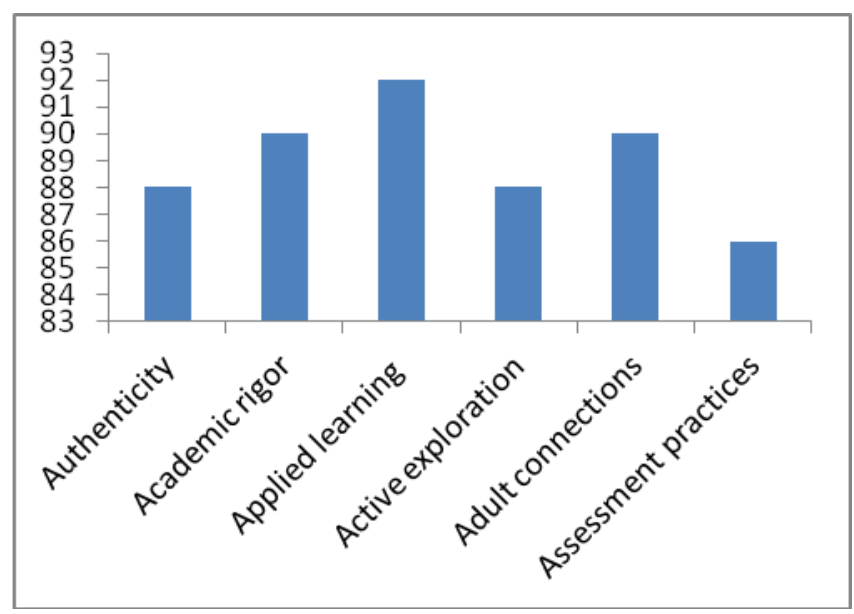

Fig. 4 Six A's of project based learning

Six A's of project based learning are depicted in figure 4. The percentage of achievement of these six A's by learners have been analyzed by gathering feedback data and found that project based learning has benefitted the learners.

\section{A. Authenticity}

Learners have learnt the authenticity of the project which means the project emerges out from a problem or question that has meaning and they create or produce something that has personal or social value.

B. Academic Rigor

The project leads learners to achieve academic rigor by acquiring and applying knowledge central to one or more disciplines. Learners have developed higher order thinking skills and habits of searching for evidence by taking different perspectives.

C. Applied Learning
Learners have solved a real life problem that is grounded in the context of life. The projects have led learners to acquire and use competencies expected in highperformance work organizations such as teamwork, appropriate use of technology, problem solving, and communications. The work required learners to develop organizational and self-management skills.

D. Active Exploration

Learners spend significant amounts of time doing fieldbased work. The project required learners to engage in real investigation, using a variety of methods, media, and sources. Learners communicated what they have learnt through presentations.

\section{E. Adult Connections}

Learners had opportunities to meet and observe adults with relevant expertise and experience. Adults from outside the classroom helped learners develop a sense of the realworld standards for project work.

F. Assessment Practices

Learners had opportunities to review similar work products. There were clear milestones at the completion of each distinct phase of the work, culminating in an exhibition, portfolio, or presentation. Learners received timely feedback on their works in progress and engage in periodic, structured, self-assessment using clear project criteria that they have helped to set.

\section{Conclusions}

The role of the teacher is not just to dispense information, but to become a co-investigator with students, a thinking coach and a facilitator. In project based active learning method, the learning is by means of doing practically. It prompts students to collaborate while at the same time support self-directed learning. The soft skills: collaboration, decision making, self-learning, effective communication with project-mates and people outside classroom and presentation skills in team are developed. Projects have connected students to their own interests and talents, to others in the community, and to the community at large foster active engagement with course content and with real-life tasks and responsibilities. From analysis, it is seen that students have attained the course outcome as well as developed in them soft skills. Students experienced selfdirected learning and felt teacher as problem-solving colleague.

\section{References}

[1] Bonwell, C.C., and J. A. Eison (1991), Active Learning: Creating Excitement in the Classroom, Asheeric Higher Education Report No. 1, George Washington University, Washington, DC.

[2] Sara Jane Coffman, Ten Strategies for Getting Students to Take Responsibility for their Learning, College Teaching Journal, 51 (1), ISSN 8756-7555.

[3] Felder, R.M., and Silverman, L.K. (1988), Learning and Teaching Styles in Engineering Education, Engineering Education, 78(7), 674-681. [4] Feden, P., and R. Vogel (2003), Methods of Teaching: Applying Cognitive Science to Promote Student Learning, Mcgraw Hill Higher Education

[5] Arra, C. T., D’Antonio, M. D., \& D'Antonio Jr., M. (2011), Students' Preferences for Cooperative Learning Instructional Approaches: Considerations for College Teachers. Journal of Research in Education, 21, 114-126. 
[7] Joy M. Reid (1987), The Learning Style Preferences of ESL Students, Colorado State University, TESOL quarterly, Vol. 21(1), 87-110

[8] Sara Jane Coffman, Ten Strategies for Getting Students to Take Responsibility for their Learning, College Teaching Journal, 51 (1), ISSN 8756-7555.

[9] Lawrence, G. (1993), People Types and Tiger Stripes: A Practical Guide to Learning Styles, 3rd Ed., Gainesville, Fla.: Center for Applications of Psychological Type.

[10] Richard M. Felder, Rebecca Brent (2005), Understanding Student Differences, Journal of Engineering Education, 94 (1), 57-72.

[11] Felder, R.M. (1989), Meet Your Students: 1. Stan and Nathan, Chemical Engineering Education, 23(2), 68-69.

[12] J R Dhage, M S Patil, A B Pawar, (2017), Implementation and Feedback Analysis of Jigsaw Active Learning Method, Journal of Engineering Education Transformations, 30 (3)

[13] M R. Jadhav, A B. Kakade, M. S. Patil, (2018), ICT and Active Teaching-Learning-Assessment Process in the Engineering Education, Journal of Engineering Education Transformations, 31 (3),

[14] Prasanna Kumar MK, Soniya Agrawal, Hemachandra Bhat, (2016), Effectiveness of Project Based Learning on Outcome Based Education- A case study, Journal of Engineering Education Transformations, 29 (3),

[15] Millis, B., And P. Cottell, Jr. (1998), Cooperative Learning for Higher Education Faculty, American Council on Education, ORYX Press.

[16] Bruffee, K. (1995), Sharing Our Toys: Cooperative Learning Versus Collaborative Learning, 12-18.

[17] Johnson, D., R., Johnson, and K. Smith (1998), Active Learning: Cooperation in the College Classroom, 2nd Ed., Interaction Book Co., Edina.

\begin{tabular}{|c|c|c|c|c|c|}
\hline \multirow{2}{*}{$\begin{array}{l}\text { Sr. } \\
\text { No }\end{array}$} & \multirow{2}{*}{$\begin{array}{l}\text { Feedback Questions } \\
\text { Rate the following activities }\end{array}$} & \multicolumn{4}{|c|}{ Rating given by students for PBL activity } \\
\hline & & Poor (1) & Average (2) & Good (3) & Excellent (4) \\
\hline 1 & $\begin{array}{l}\text { Involvement in project area and application } \\
\text { selection }\end{array}$ & & & & \\
\hline 2 & Self-learning of sensor data sheet & & & & \\
\hline 3 & Emphasis on using current tools and technologies & & & & \\
\hline 4 & $\begin{array}{l}\text { Involvement of students in activities outside } \\
\text { classroom }\end{array}$ & & & & \\
\hline 5 & Involvement of students in raising doubts & & & & \\
\hline 6 & $\begin{array}{l}\text { Opportunities in making individual and group } \\
\text { decisions }\end{array}$ & & & & \\
\hline 7 & $\begin{array}{l}\text { Improvement in verbal and written skills through } \\
\text { demonstration of project and project report }\end{array}$ & & & & \\
\hline
\end{tabular}

[18] Johnson, D., R., Johnson, and K. Smith (1998), Cooperative Learning Returns to College: What Evidence is there that it Works? $30(4), 26-35$.

Table 2. Rubrics for individual assessment of ISE evaluation

\begin{tabular}{|l|l|l|l|l|}
\hline & \multicolumn{1}{|c|}{ Barely acceptable } & \multicolumn{1}{|c|}{ Fair } & \multicolumn{1}{c|}{ Good } \\
\hline $\begin{array}{l}\text { Identification of project } \\
\text { application and } \\
\text { formulation of problem }\end{array}$ & $\begin{array}{l}\text { Lack of self-study for } \\
\text { identification of } \\
\text { application }\end{array}$ & $\begin{array}{l}\text { Self-study with basic } \\
\text { knowledge and } \\
\text { identification of } \\
\text { application }\end{array}$ & $\begin{array}{l}\text { Self-study with good } \\
\text { knowledge and identification } \\
\text { of doable application for } \\
\text { project }\end{array}$ & $\begin{array}{l}\text { Self-study with very good } \\
\text { knowledge and selection of } \\
\text { doable application for project }\end{array}$ \\
\hline $\begin{array}{l}\text { Sensor data sheet study- } \\
\text { operation, working and } \\
\text { selection }\end{array}$ & $\begin{array}{l}\text { Neither studied nor } \\
\text { identified sensors, } \\
\text { incomplete and } \\
\text { improper specifications } \\
\text { selected sensor as per } \\
\text { requirement/ specifications } \\
\text { with understanding } \\
\text { specifications }\end{array}$ & $\begin{array}{l}\text { Well defined and studied } \\
\text { every parameter of sensor, } \\
\text { selected as per } \\
\text { specifications with clear } \\
\text { understanding }\end{array}$ \\
\hline Use of sensor in project & Inappropriate & Used without taking in to & Used but some of the & Used sensor effectively by \\
\hline
\end{tabular}


Journal of Engineering Education Transformations, Volume 33, January 2020, Special issue, eISSN 2394-1707

\begin{tabular}{|l|l|l|l|l|}
\hline & explanation and use & $\begin{array}{l}\text { consideration parameters } \\
\text { of sensor }\end{array}$ & parameters are considered & considering all parameters \\
\hline $\begin{array}{l}\text { Project demonstration, } \\
\text { project report }\end{array}$ & $\begin{array}{l}\text { Results are not properly } \\
\text { presented and } \\
\text { documented }\end{array}$ & $\begin{array}{l}\text { Some of the results are } \\
\text { presented }\end{array}$ & $\begin{array}{l}\text { All results are presented but } \\
\text { no effective communication }\end{array}$ & $\begin{array}{l}\text { All results are presented with } \\
\text { effective communication and } \\
\text { documented properly. }\end{array}$ \\
\hline $\begin{array}{l}\text { Outside classroom } \\
\text { engagement and learning }\end{array}$ & $\begin{array}{l}\text { Learners have not spent } \\
\text { time in learning/doing } \\
\text { project tasks }\end{array}$ & $\begin{array}{l}\text { Learners have spent little } \\
\text { time in learning/doing } \\
\text { projects tasks }\end{array}$ & $\begin{array}{l}\text { Learners have spent } \\
\text { sufficient time in learning } \\
\text { and answered some } \\
\text { questions asked on projects } \\
\text { sufficient time in doing } \\
\text { project tasks and answered } \\
\text { satisfactorily all questions } \\
\text { asked }\end{array}$ \\
\hline Team work & $\begin{array}{l}\text { Does not perform any } \\
\text { duties assigned and } \\
\text { relies on others }\end{array}$ & $\begin{array}{l}\text { Rarely performs all } \\
\text { assigned duties in team } \\
\text { in team and motivates others } \\
\text { for completion of tasks. }\end{array}$ & $\begin{array}{l}\text { Perform nearly all assigned } \\
\text { duties in team }\end{array}$ \\
\hline
\end{tabular}

Table 3. Individual and group assessment

\begin{tabular}{|c|c|c|c|c|}
\hline \multicolumn{5}{|c|}{ Group Assessment GA (To be filled by faculty for $15 \mathrm{M}$ ) } \\
\hline Sr. No. & \multicolumn{2}{|c|}{ Rubrics (each metric 5M) (5-Excellent, 4- Good, 3-Average, 1-Poor) } & \multicolumn{2}{|r|}{ Marks } \\
\hline 1 & \multicolumn{2}{|c|}{$\begin{array}{l}\text { Identification and Selection of application for project, Data sheet study, } \\
\text { selection of sensor, Methodology }(5 \mathrm{M})\end{array}$} & & \\
\hline 2 & \multicolumn{2}{|l|}{ Project plan execution, time management, Team work (5M) } & & \\
\hline 3 & \multicolumn{2}{|l|}{ Interpersonal skills $(5 \mathrm{M})$} & & \\
\hline & \multicolumn{2}{|l|}{ Total GA marks } & & \\
\hline \multicolumn{5}{|c|}{ Individual Assessment (To be filled by faculty for $10 \mathrm{M}$ ) } \\
\hline Sr. No. & Name of Students & PRN NO & IA & $\begin{array}{c}\text { GA+IA } \\
\text { Total marks }\end{array}$ \\
\hline \multicolumn{5}{|l|}{1} \\
\hline \multicolumn{5}{|l|}{2} \\
\hline \multicolumn{5}{|l|}{3} \\
\hline 4 & & & & \\
\hline
\end{tabular}

